\title{
WYCHOWANIE DOJRZAŁEGO CHRZEŚCIJANINA JAKO NOWEGO CZŁOWIEKA W CHRYSTUSIE WEDłUG KS. FRANCISZKA BLACHNICKIEGO
}

DOI: http://dx.doi.org/10.12775/TiCz.2021.021

Streszczenie. Ks. Franciszka Blachnickiego trzeba uznać za naukowca, który jest świadkiem. Świadek to człowiek, u którego jest pełna harmonia między tym, co myśli, co mówi, a tym, jak żyje. Szczególnie dziś, gdy zauważamy upadek autorytetów wychowawczych, świadectwo życia jest ważniejsze od wiedzy, którą wychowawca też przekazuje.

Niniejsze refleksje zostały zatytułowane: Wychowanie dojrzałego chrześcijanina jako nowego człowieka w Chrystusie według ks. Franciszka Blachnickiego. Profesor Antoni Jozafat Nowak w książce Homo novus (Lublin 2002) mówi, że człowiek powinien pozwolić, aby Chrystus wychował (uformował) człowieka na obraz Boga, który został wpisany w struktury osoby ludzkiej w fakcie stworzenia. Dlaczego Chrystus? Św. Jan pisze: „Boga nikt nigdy nie widział. Jednorodzony Bóg [Jezus, przyp. I.W.], który jest w łonie Ojca, On nam Go objawił" (J 1,18). To znaczy, że Chrystus ma największe szanse na to, aby uformować człowieka na obraz Boga.

Wychowanie dojrzałego chrześcijanina w publikacjach ks. Blachnickiego jest bardzo szczegółowo omawiane. W niniejszym artykule skupimy się tylko na sposobach i pomocach w wychowaniu nowego człowieka, na jego osobowości oraz na wzorach osobowych dla nowego człowieka

Słowa kluczowe: wychowanie; nowy człowiek; Pismo Święte; modlitwa; liturgia; Chrystus; Maryja; Duch Święty. 
Abstract. Education of a Mature Christian as a New Man in Christ according to Fr. Franciszek Blachnicki. Fr. Franciszek Blachnicki should be considered a scholar who is a witness. A witness is a person in whom there is complete harmony between what he thinks, what he says and how he lives. Especially today, when we notice the decline of educational authorities, the testimony of life is more important than the knowledge that the educator also transmits.

These reflections are entitled: Education of a Mature Christian as a New Man in Christ according to Fr. Franciszek Blachnicki. In his book Homo novus (Lublin, 2002), Professor Antoni Jozafat Nowak says that man should allow Christ to educate (mold) him in the image of God as inscribed in the structures of the human person in the fact of creation. Why Christ? Saint John writes: "No one has ever seen God: the only Son [Jesus, fn. I.W.], who is in the bosom of the Father, he has made Him known" (John 1:18). This means that Christ has the best chance of molding man in the image of God.

The education of a mature Christian is discussed in great detail in Fr. Blachnicki's publications. In this article, we will focus only on the methods and aids in raising a new person, on his personality and on personal role models for the new man.

Keywords: upbringing; education; new man; Holy Bible; prayer; liturgy; Christ; Mary; Holy Spirit.

Postawa życiowa ks. Franciszka Blachnickiego pozwala wyprowadzić wniosek, że jest on naukowcem, który swoim życiem potwierdza to, co głosi, jest więc świadkiem. Papież Paweł VI podczas jednej audiencji powiedział, że świat współczesny chce słuchać świadków, a nauczycieli słucha w takim stopniu, w jakim są świadkami. Warto zwrócić uwagę na to, że słowa te wypowiedział papież pięćdziesiąt lat temu. Zapewne wtedy nie było tak wiele i tak szybko przepływających informacji jak dziś. Dziś niektóre informacje są zniekształcane, czyli są deformacjami, a nie informacjami. Dlatego dziś w procesie wychowania świadectwo jest jeszcze ważniejsze niż wtedy, kiedy papież wypowiadał te słowa ${ }^{1}$.

Wychowanie dojrzałego chrześcijanina w publikacjach ks. Blachnickiego jest bardzo szczegółowo omawiane. W niniejszym artykule skupimy się tylko na sposobach i pomocach w wychowaniu nowego człowie-

${ }^{1}$ Czasem używamy słowa świadek. Ogólnie znamy jego treść, ale gdyby poproszono nas o podanie definicji świadka, pewnie byśmy powiedzieli: „muszę się zastanowić” albo „muszę poszukać w jakimś słowniku czy encyklopedii”. W definicji świadka zaproponowanej przeze mnie, na użytek niniejszych refleksji, chcę zwrócić uwagę na tzw. tożsamość osobową świadka. Świadek to ten, u którego nie ma żadnego rozdźwięku między tym, co myśli, mówi i jak postępuje. 
ka, na jego osobowości oraz na wzorach osobowych, do których powinien dorastać.

\section{SPOSOBY WYCHOWANIA NOWEGO CZŁOWIEKA}

Po określeniu ideału formacyjnego, którym jest nowy człowiek, Założyciel Ruchu Światło-Życie wskazywał na możliwości realizacji tego ideału.

Podstawą wychowania proponowanego przez ks. Franciszka Blachnickiego jest osobowa relacja z Jezusem jako Panem „mojego” życia i „moim” Zbawicielem². Przez dobrowolnie podjętą osobistą decyzję wejścia w relacje z Jezusem członek Ruchu Światło-Życie ma szansę pogłębiać życie w Duchu Świętym, poddając się procesowi rozwoju duchowego. Zamierzeniem Ruchu jest ukształtowanie postawy dojrzałego chrześcijanina. Ten wysiłek wychowawczy ks. Franciszek nazwał „pedagogią nowego człowieka”.

Pierwszy sposób (metodę wychowawczą) wyrażają dwa greckie słowa Fos-Dzoe (Światło-Życie), wpisane w formę krzyża. Taki układ wskazuje na nierozerwalną jedność światła i życia. Ks. Blachnicki wydobył symbol światła $\mathrm{z}$ medytacji nad Biblią, która ukazuje wielowymiarowe znaczenie światła. Światło pozwala też poznać prawdę, która z kolei może prowadzić człowieka do wolności duchowej (por. J 8,31). Z analizy tekstów biblijnych wynika, że istnieje organiczny związek pomiędzy oświeceniem umysłu i światłem, które oznacza przejrzenie człowieka, a jego wolnością i wyzwoleniem. W tych relacjach można dostrzec klucz do zrozumienia istoty wychowania ${ }^{3}$.

Ksiądz Blachnicki uważał, że metoda wychowawcza światła domaga się rozwoju życia duchowego do poziomu poznania prawdy, która powinna stać się normą postępowania członka Ruchu. Prawda objawiona w słowie Życia (w Biblii) powinna więc być przyjmowana jako prawo życia - jako przykazanie. Wielokrotnie tłumacząc znaczenie symbolu Fos-Dzoe, ks. Franciszek podkreślał, że prawda Boża nie jest nam dana tyl-

2 Sformułowania: „mojego życia” i „moim” podkreślają bardzo osobistą relację do Jezusa, mogą odnosić się do każdej osoby.

${ }^{3}$ Por. F. Blachnicki, Prawda - Krzyż - Wyzwolenie. Ku polskiej teologii wyzwolenia, Carlsberg 1985, s. 21-22. 
ko dla oświecenia umysłu czy wzbogacenia wiedzy, lecz zawsze jest wezwaniem skierowanym do całej osoby i domaga się wprowadzenia jej w życie.

Jednym z głównych założeń tej metody jest też stworzenie warunków dla egzystencjalnego przeżywania wiary. Dążenie do jedności między światłem wiary a życiem powinno się wyrażać w codziennych konkretnych sytuacjach, w których należy podejmować różne decyzje 4 . Metodę odnoszącą się do światła można uznać za wiodącą w wychowywaniu członków Ruchu do dojrzałości chrześcijańskiej, ponieważ jest ona zawarta w samej nazwie Ruchu Światło-Życie.

Według ks. Blachnickiego w znaczeniu najpełniejszym światłem dla człowieka jest sam Jezus ${ }^{5}$. Założyciel Ruchu często przypominał, że najlepszą drogą do poznania Jezusa jako Światłości jest medytacja nad słowem Bożym. Medytacja - to znaczy rozważanie słowa Bożego w kontekście swojego życia; wówczas Jezus staje się Światłością w „moim” życiu. W nawiązaniu do Konstytucji dogmatycznej o Kościele Soboru Watykańskiego II ks. Blachnicki twierdził, że światłość Jezusa jest przekazywana chrześcijanom przez Kościół. Dlatego w świetle Kościoła chrześcijanin może w sposób najbardziej prawidłowy dojrzewać do pełni osobowej ${ }^{6}$.

Jeżeli człowiek zdecyduje się stawać w świetle, wówczas jest w stanie zobaczyć prawdę o sobie. Przyjęcie prawdy o sobie zawsze jest uważane za pierwszy warunek rozwoju człowieka. Ks. Blachnicki w sposób szczegółowy omawia płaszczyzny osobowe, które powinny się rozwijać za sprawą światła.

Pierwsza płaszczyzna dotyczy rozumu. Dzięki światłu człowiek jako istota rozumna jest zdolny odkryć podstawowe prawa dotyczące jego samego i świata. Jako istota wolna człowiek może podjąć decyzję podporządkowania się prawom poznanym rozumowo. Tę zdolność rozumu założyciel Ruchu Światło-Życie nazywa mądrością, a nie wiedzą. Wiedza odnosi się do płaszczyzny teoretycznej, mądrość zaś polega na prawidłowym zastosowaniu wiedzy w odniesieniu do życia. Dzięki mądrości oso-

4 F. Blachnicki, Charyzmat „Światło-Życie”. Teksty podstawowe, Lublin 1987, s. 36. 5 „Ja jestem światłością świata. Kto idzie za Mną, nie będzie chodził w ciemności, lecz będzie miał światło życia” (J 8,12).

6 Por. E. Kusz, „Światło-Życie” jako integralna wizja wychowania, „Ethos” 6 (1993) 23, s. 164 . 
ba zdobywa coraz to większe doświadczenie życiowe i staje się coraz bogatsza duchowo ${ }^{7}$.

Drugą płaszczyzną jest sumienie. Dzięki światłu sumienie jest zdolne odróżniać dobro od zła, poznawać wartości itd. Większość psychologów twierdzi, że przyjęta hierarchia wartości ma największy wpływ na rozwój człowieka. Trzeba pamiętać, że choć mówimy o różnych wymiarach osobowości człowieka, to jednak tworzą one logiczną i organiczną jedność. Dlatego wartości, poznawane jako pozytywne - twórcze, zachęcają sumienie do podjęcia decyzji, aby włączyć je w doświadczenie życia. Ponieważ człowiek jest osobą wolną, dokonuje więc wyboru i włącza kolejno w doświadczenie swego życia wartości, poczynając od najważniejszej według niego ${ }^{8}$.

W kontekście omawiania płaszczyzn rozwojowych w człowieku ks. Blachnicki podkreśla potrzebę formowania integralnego człowieka.

Kolejna metoda wychowawcza pozwalająca realizować drogę ku dojrzałości jest zawarta w letnich rekolekcjach oazowych.

\section{POMOCE W WYCHOWANIU NOWEGO CZŁOWIEKA}

\subsection{SŁOWO BOŻE}

Ksiądz Blachnicki proponuje, aby w wychowaniu dojrzałego chrześcijanina wykorzystać szanse, jakie daje słowo Boże $e^{9}$. Jego zdaniem celem tego wychowania jest ukształtowanie właściwej postawy wobec słowa Bożego ${ }^{10}$. Często powtarzał, że „powinniśmy karmić się słowem Bożym jak codziennym chlebem”. Proponował też modlitewne karmienie się słowem Bożym, które ma stawać się słowem życia, temu służy „Namiot Spotkania”. Uczył też jak prawidłowo słuchać słowa Bożego. Prawidłowe słuchanie słowa Bożego powinno rodzić w słuchaczu przekonanie, że jest

7 F. Blachnicki, Prawda - Krzyż - Wyzwolenie, s. 44.

8 Por. tamże.

9 Były to trudne czasy, w których oficjalnie w Polsce drukowanie Pisma Świętego było bardzo utrudnione. Ks. Franciszek korzystał ze swoich znajomości, szczególnie w krajach, gdzie można było drukować Pismo Święte. I bardzo często było ono przemycane do nas.

10 Por. Pomoce formacyjne do kroku 5, s. 25-28. 
to słowo osobiście skierowane do niego. Odwołując się do Biblii, Założyciel Ruchu Światło-Życie wskazywał, że dojrzewania do właściwego słuchania słowa Bożego można się uczyć od Proroka Samuela, który jako młodzieniec służył Bogu, pod opieką kapłana Helego. „Pewnej nocy. [...] Było to w świątyni Pana w pobliżu Arki Bożej. [...] Pan zawołał Samuela" (1 Sm 3,2-4). Początkowo w głosie, który Samuel słyszał, nie rozpoznał głosu Boga (por. 1 Sm 3,1-21). Myślał, że jest to głos kapłana Helego. Ponieważ „[... Samuel jeszcze nie znał Pana, bo jeszcze Pan mu się nie objawiał" (1 Sm 3,7). Kiedy po raz trzeci Bóg zawołał Samuela i on znów poszedł do Helego, „Heli zrozumiał, że to Pan woła chłopca” (1 Sm 3,8). Samuel za pomocą wychowawczej postawy Helego dojrzewa do właściwego słuchania słowa Bożego. W jego postawie dostrzegamy dwie cechy: wiary i ufności dziecięcej. Taka postawa stwarza szanse na prawidłowe słuchanie i odczytywanie słowa Bożego, a otwarcie się na dary Ducha Świętego uzdalnia do wypełnienia Słowa.

\subsection{MODLITWA}

Założyciel Ruchu Światło-Życie w sposób organiczny wpisywał modlitwę w Znak Ruchu, który ukazuje program życia chrześcijańskiego. Polega on na stałym dążeniu do tego, aby światło prawdy Bożej, odcztanej w słowie Bożym, wprowadzić w życie - uczynić zasadą działania i postępowania. Jest to istotny przedmiot całej pracy duchowej, która zmierza do wychowania nowego człowieka ${ }^{11}$.

Ksiądz Blachnicki najpierw ukazywał pozytywną rolę modlitwy w życiu duchowym człowieka. Porównywał ją do oddechu, który jest oznaką biologiczno-psychicznego życia człowieka, modlitwa zaś jest oznaką duchowego życia człowieka ${ }^{12}$. Modlitwa pełni też rolę mechanizmu obronnego przed upadkiem duchowym, a nawet fizycznym.

11 Pro. F. Blachnicki, Panie naucz nas modlić się, cz. 1, Krościenko 1999, s. 29.

12 Por. Wychowanie do modlitwy, Lublin 1995, s. 2-4. 


\subsection{LITURGIA}

Trudno powiedzieć, na ile sługa Boży znał duchowość chrześcijańskiego Wschodu, który wychowuje swoich wiernych przede wszystkim przez liturgię. W katechezach formacyjnych ks. Franciszka wyczuwało się przekonanie, że liturgia jest najważniejszą szkołą wychowania nowego człowieka $^{13}$. W ukazywaniu wychowawczej roli liturgii ks. Blachnicki nie odwoływał się wprost do psychopedagogiki, ale istotne wskazania wychowawcze tej dziedziny wiedzy są obecne w jego wskazaniach wychowawczych, np. liturgia nie tylko formuje cechy osobowe nowego człowieka, ale uczy właściwych postaw wobec otoczenia, a przede wszystkim wobec Kościoła jako wspólnoty Ludu Bożego. Te wypowiedzi też potwierdza psychologia, która omawiając cechy osobowe człowieka, dawniej koncentrowała się głównie na opisywaniu cech osobowych. Aktualnie psychologia opisuje te cechy w kontekście społecznym. Mądrość serca podpowiadała ks. Franciszkowi, że prawidłowy udział w liturgii uczy człowieka nowej kultury jako postawy życiowej.

Liturgia jako wychowawca najpierw domaga się wysiłku rozumu, aby światło przekazywane przez znaki i symbole zajaśniało w „naszym” umyśle. Następnie potrzebne jest podporządkowanie się poznanym treściom i zaangażowanie jako akt wolnej woli człowieka ${ }^{14}$. Spośród sprawowanych sakramentów, korzystając z nauczania Soboru Watykańskiego II, ks. Blachnicki przekonywał, że Eucharystia ma największe możliwości wychowawcze. Uczestnik Eucharystii, w słowie Bożym i w przeistoczeniu sakramentalnym, powinien odczuwać żywą obecność Chrystusa.

Ukonkretnienia powyższej prawdy doświadczyłem jako student Katolickiego Uniwersytetu Lubelskiego, gdy odprawiałem raz w tygodniu Mszę św. dla niewielkiej grupy, która gromadziła się wokół ołtarza. Kiedyś był czytany fragment Ewangelii według św. Marka 13,41-44, jak Jezus siedział w świątyni jerozolimskiej naprzeciw skarbony i przypatrywał się tym, którzy wrzucali pieniądze. Bogaci wrzucali więcej niż biedni. Zauważył, że pewna uboga wdowa wrzuciła tylko „dwa pieniążki”, i stwierdził, że ona wrzuciła więcej niż inni. „Wszyscy bowiem wrzucali z tego, co im

13 Dziesięć kroków ku dojrzałości chrześcijańskiej. Pomoce formacyjne do spotkań i celebracji, Krościenko 2000, s. 140-149.

14 Por. F. Blachnicki, Charyzmat „Światło-Życie”, s. 52. 
zbywało, a ona ze swego ubóstwa wrzuciła wszystko, co miała, całe swoje utrzymanie" (Mk 13,44). Po przeczytaniu tekstu zachęciłem uczestników, aby podzieli się osobistym doświadczeniem; co ta Ewangelia komuś mówi. Po chwili ciszy odezwała się studentka i powiedziała: „Uświadomiłam sobie, że Jezus w tej chwili na mnie patrzy i zadaję sobie pytanie: czy stać by mnie było na taką ofiarę, jaką złożyła ta uboga wdowa?”. Była to wielka lekcja, którą pamiętam do dziś.

\section{OSOBOWOŚĆ DOJRZAŁEGO CHRZEŚCIJANINA - NOWEGO CZŁOWIEKA ${ }^{15}$}

Słowo „dojrzewanie” zawiera w swej treści rozwój, który zawsze łączy się z trudem. Znana psycholog (Maria Grzywak-Kaczyńska) pisze, że w naturę przyrody rozwój jest wpisany w sposób rytmiczny. Dynamizm rozwoju u zwierząt wpisany jest instynkt przekazywania życia. Człowiek natomiast sam musi podjąć wysiłek zmierzający do rozwoju ${ }^{16}$. $Z$ różnych względów niektórzy nie podejmują owego trudu i to zawsze ma negatywne konsekwencje dla nich ${ }^{17}$. Ale, jeżeli człowiek podejmie trud związany z rozwojem, zawsze doświadcza pozytywnych owoców tego trudu. Pedagogika personalistyczna jako główny owoc rozwoju wymienia dojrzałość osobową ${ }^{18}$. Chrześcijańska pedagogika personalistyczna wzór dojrzałej osobowości i wzór dojrzałej postawy duchowej zawsze widziała w Chrystusie ${ }^{19}$.

Stary człowiek, według ks. Blachnickiego, to człowiek oddzielony od Boga, żyjący w grzechu, niezdolny do wchodzenia w prawidłowe relacje, rozbity wewnętrznie, zamknięty w swych egoistycznych celach. Sługa

$15 \mathrm{Z}$ analizy głównych myśli założyciela Ruchu Światło-Życie widać, że pojęcia: „dojrzały chrześcijanin” i nowy człowiek treściowo pokrywają się, dlatego w niniejszych rozważaniach będą używane zamiennie.

16 Por. M. Grzywak-Kaczyńska, Trud rozwoju, Warszawa 1988, s. 15-17.

17 Por. K. Dąbrowski, Trud istnienia, Warszawa 1986, s. 19; por. także Jan Paweł II, Przemówienia, homilie w Polsce 31 maja - 10 czerwca 1997, Kraków 1997, s. 78.

18 Por. H. Posłuszny, Potrzeby w służbie rozwoju dojrzałej osobowości, „Studia Włocławskie” 3 (2000), s. 241-245.

19 Gabriel Mar [Fr. Blachnicki], Problem formalnej zasady teologii pastoralnej i duszpasterstwa, AK 69 (1966), s. 242. 
Boży mówił, że większość ludzi żyje poniżej tego, kim powinni być. Z biblijnego opisu upadku pierwszych ludzi można wyprowadzić wniosek, że człowiek nie posługiwał się wolnością zgodnie z wolą Boga, lecz zdegradował wolność, sprowadzając ją do niezależności wobec Stwórcy. Źle pojmując wolność, człowiek odrzuca zalecenia Boże, które kojarzą mu się z ograniczeniem, skrępowaniem. Takie pojmowanie wolności prowadzi do postawy nieodpowiedzialności i powoduje, że człowiek siebie czyni kryterium dobra i zła ${ }^{20}$. Jest to złudne pojmowanie wolności, które towarzyszy współczesnemu człowiekowi, często żyjącemu w nieświadomości, że dążąc do subiektywnie pojmowanej wolności, jest uwikłany w różne uzależnienia, w tym również uzależnienie od grzechu. W jakimś wymiarze ks. Blachnicki był przerażony tym, że na co dzień w grzechu żyje większość wiernych. Dlatego odwołując się do nauki św. Pawła na temat nowego człowieka, mówił, że „nowy człowiek” to określenie chrześcijanina, który swoje istnienie zawdzięcza Bogu Ojcu (por. 1 Kor 1,30) i Jezusowi (por. 1 Kor 8,6), a Duch Święty, który mieszka w człowieku, wciąż dynamizuje ten nowy wymiar życia (por. 1 Kor 3,16; 6,19-20).

Nowy człowiek jest świadomy swojej godności jako osoby, swoje życie podporządkowuje Bogu, czyni z siebie bezinteresowny dar, tzn. dzieli się swoim czasem, zdolnościami z innymi ludźmi. Wychowanie nowego człowieka polega na rozwijaniu i doskonaleniu w sobie miłości agape, czyli bezinteresownej miłości. W życiu nowego człowieka zachodzi jedność pomiędzy prawdami uznawanymi za słuszne a tymi, według których postępuje, to człowiek prawdziwie wolny.

W obrazie nowego człowieka w ujęciu ks. Blachnickiego można dostrzec podobieństwo do obrazu nowego człowieka ukazanego przez św. Pawła w Liście do Kolosan. Przełomowym wydarzeniem w życiu Kolosan było przyjęcie chrztu, który pozwala przejść ze śmierci duchowej do nowego życia w Chrystusie. W sakramencie chrztu Chrystus obdarzył Kolosan nowym życiem, które związane jest z przyoblekaniem nowego człowieka, wciąż się odnawiającego według obrazu Boga (por. Kol 3, 10). W sakramencie chrztu „stary człowiek” zostaje odnowiony na podobieństwo Stwórcy, ponieważ został ochrzczony w imię Jezusa Chrystusa. Jan Paweł II w Liście apostolskim Novo millenio ineunte głosił, że do czasu

20 Por. F. Blachnicki, Prawda - Krzyż - Wyzwolenie, 39-41. 
przyjęcia chrztu, wejście na drogę nowego człowieka jest propozycją, którą można przyjąć lub odrzucić. Natomiast od chwili przyjęcia chrztu dojrzewanie do coraz pełniejszego stawania się „obrazem” Boga jest zobowiązaniem $^{21}$.

Wśród przeszkód na drodze rozwoju duchowego ks. Blachnicki często wymieniał lęk egzystencjalny występujący w człowieku. Mówił, że nieraz ktoś potrafi się oprzeć jakiejś przemocy zewnętrznej, potrafi być wolny wobec zła, a jest zniewolony lękiem tkwiącym wewnątrz osoby. W sytuacji lęku osoba nie jest wolna w działaniu, stąd racje podejmowanego działania nie są obiektywne i właściwe. Motywem podejmowanego działania u człowieka zniewolonego lękiem może być obawa przed otoczeniem, np. żeby otoczenie „mnie” nie wyśmiało. Człowieka zniewolonego lękiem ks. Blachnicki określa jako „człowieka stada”, który robi to, czego życzą sobie inni ${ }^{22}$. Na płaszczyźnie duchowej poważnym brakiem człowieka zniewolonego lękiem jest to, że teoretycznie uznaje prawdy objawione, natomiast nie potrafi wejść w osobowe relacje z Bogiem. Taki człowiek przeważnie wyobraża sobie Boga jako surowego sędziego i żyje w ciągłym lęku przed $\mathrm{Nim}^{23}$.

\section{WZORY OSOBOWE W WYCHOWANIU NOWEGO CZŁOWIEKA}

Blachnicki uważa, że podstawa wychowania dojrzałego chrześcijanina - nowego człowieka w Chrystusie, powinna opierać się na żywej wierze $^{24}$. Osobowymi wzorami wychowania nowego człowieka jest Jezus Chrystus i Maryja. Analizując przemyślenia Blachnickiego na ten temat, można przekonać się, że jego osobiste relacje z Chrystusem miały charakter mistyczny ${ }^{25}$. Dlatego uważał, że do osiągnięcia dojrzałości duchowej,

${ }^{21}$ Por. Jan Paweł II, NMI, nr 30-31.

22 Por. F. Blachnicki, Charyzmat „Światło-Życie”, s. 33-34.

23 Tenże, Prawda - Krzyż - Wyzwolenie, s. 29.

${ }^{24}$ Por. Biblioteka Animatora. Formacja podstawowa Służby Liturgicznej i Ruchu Światło-Życie, Kraków 1989, s. 40-42.

${ }^{25} \mathrm{~W}$ formacji duchowej mówi się o dwu wymiarach dojrzewania duchowego: wymiarze ascetycznym (wstępującym), który polega na systematycznym wysiłku zmierzającym do osiągania coraz głębszego zjednoczenia z Jezusem i wymiarze mistycznym (zstępującym), który polega na coraz większym zgadzaniu się z wolą Boga, która jest wolą 
nie wystarczą relacje ascetyczne, ale potrzebne są relacje mistyczne ${ }^{26}$. Od strony intelektualnej przekonania ks. Franciszka w tym zakresie dojrzewały dzięki medytacji Pisma Świętego. Dlatego Założyciel Ruchu Światło-Życie w prowadzonych przez siebie rekolekcjach czy głoszonych homiliach lub katechezach wskazywał na to, aby mieć obraz Chrystusa zgodny z Pismem Świętym ${ }^{27}$. Ten obraz trzeba ciągle weryfikować, przez analizowanie „moich” dotychczasowych relacji z Chrystusem i ich identyfikację z postawą Chrystusa ukazywaną przez Biblię ${ }^{28}$.

W postawie wychowawczej ks. Blachnickiego można dostrzec wysoki poziom dojrzałości, wyrażającej się np. w tym, że wychowanek powinien świadomie i dobrowolnie zaakceptować, że „[...] Jezus Chrystus jest moim Światłem i Życiem oraz jedyną drogą do Ojca" ${ }^{29}$. Według niego, tę prawdę najgłębiej oddają słowa Ewangelii według św. Jana: „A nikt nie wstąpił do nieba poza Tym, który z niego przybył - Synem Człowieczym. Podobnie jak Mojżesz na pustyni wywyższył węża, tak też jest konieczne wywyższenie Syna Człowieczego, aby każdy, kto w Niego wierzy, miał życie wieczne. [...] Bóg przecież nie posłał swego Syna na świat, aby go sądził, lecz aby go zbawił. Ten, kto w Niego wierzy, nie podlega sądowi; ten jednak, kto nie wierzy, już został osądzony, ponieważ nie uwierzył w to, kim jest jednorodzony Syn Boży" (J 3,13-18).

Mistyczne relacje wychowanka ${ }^{30} \mathrm{z}$ Chrystusem prowadzą go do tego, że Chrystus staje się światłem w nim samym. Wówczas wychowanek odkrywa ojcowską postawę Chrystusa, która wyraża się w miłości przebaczającej. Tutaj dostrzegamy kolejny geniusz wychowawczy sługi Bożego. Blachnicki znał realia psychiczne okresu dorastania, szczególnie ambiwalencje uczuć i idealizm młodzieńczy, które powodują, że niewłaściwa po-

Syna - pozwoleniu Chrystusowi, aby mógł bez przeszkód wychowywać człowieka do świętości. Można uznać, że dwa wymiary wychowania wyraża termin „Jezus Chrystus”. Jezus jako człowiek - wymiar ascetyczny, Chrystus jako Bóg - wymiar mistyczny.

${ }^{26}$ F. Blachnicki, Homilie, w: Oaza Nowego Życia, dzień 4.

27 Por. Pomoce formacyjne do kroku 1., s. 14.

28 Znany psycholog Józef Kozielecki jest zdania, że nie można zrozumieć osoby wierzącej, nie wiedząc, w jaki sposób pojmuje ona Boga. Por. J. Kozielecki, Z Bogiem albo bez Boga, Warszawa 1991, s. 81-83.

${ }^{29}$ F. Blachnicki, Charyzmat „Światło-Życie”, s. 64-66.

30 Szczególnie zwracał uwagę na to w katechezach do młodzieży okresu dorastania. 
stawa wychowawcy łatwo może zranić wychowanka, dlatego podkreślał, jak ważne jest świadectwo wychowawcy ${ }^{31}$.

Oprócz Chrystusa na drugim miejscu jako wzór osobowy w wychowaniu nowego człowieka ks. Franciszek ukazywał Maryję. Teologia duchowości katolickiej podkreśla, że u podstaw rozwoju życia duchowego znajduje się pokora. Dlatego ks. Franciszek ten wymiar postawy maryjnej wskazywał jako podstawę do rozwoju dojrzałego chrześcijanina. W ujmowaniu postawy Maryi odkrywamy u ks. Blachnickiego całościowe ujęcie $^{32}$. Odwołując się do sceny Zwiastowania, ks. Franciszek zwracał też uwagę na realizm w ocenianiu siebie i życiową mądrość Maryi. Realizm patrzenia na siebie widać w tym momencie, kiedy anioł mówi do Maryi: „[...] Nie bój się, Maryjo, bo Bóg Cię obdarzył łaską. Oto poczniesz i porodzisz syna, i nadasz Mu imię Jezus" (Łk 1,3-31). Sługa Boży mówił, że Maryja jest przekonana o tym, że sama z siebie nic nie może, dlatego: „[...] zapytała anioła, «jak to się stanie, skoro nie znam pożycia małżeńskiego?». Anioł jej odpowiedział: «Duch Święty zstąpi na Ciebie i osłoni Cię moc Najwyższego; dlatego Święte, które się narodzi, będzie nazwane Synem Bożym»" (Łk 1,34-46). Wierząc, że jest to możliwe, kiedy podda się mocy Ducha Świętego, odpowiedziała: „[...] Jestem służebnicą Pana, niech mi się stanie według twego słowa” (J 1,38).

Spośród cech osobowych Maryi ks. Blachnicki podkreślał też jej dziecięcą ufność i otwartość na przyjmowanie słowa Bożego, które zawsze rozważała w swoim sercu ${ }^{33}$. Takie przeżywanie słowa Bożego prowadzi do coraz głębszej jedności z Chrystusem.

W nawiązywaniu do postawy Maryi ks. Franciszek wskazywał też na potrzebę uległości Duchowi Świętemu ${ }^{34}$. Słusznie zwracał uwagę na to, że "nasze” wyobrażenia o Duchu Świętym są mgliste albo żadne. Dlatego wychowankom trzeba uświadamiać, że Duch Święty odgrywa bardzo ważną rolę w uświęcaniu człowieka. Sługa Boży zdawał sobie sprawę,

31 Por. F. Blachnicki, Charyzmat „Światło-Życie”, s. 65-66.

${ }^{32}$ Dokładnie takie ujmowanie postawy i osobowości człowieka proponuje psychologia personalistyczna. Por. A. Maslow, Motywacja i osobowość, Warszawa 1990, s. 386-397.

33 Por. Oazy modlitwy. Podręcznik Nowenny Jubileuszowej 2003/2004, Krościenko 2003, s. 14-16.

34 Por. Oazy modlitwy, s. 51. 
np. z trudności dotarcia do świadomości młodzieży przygotowującej się do sakramentu bierzmowania ${ }^{35}$. W katechezie przygotowującej młodzież do przyjęcia tego sakramentu Założyciel Ruchu Światło-Życie dawał konkretne wskazówki ${ }^{36}: 1$. Uwrażliwiać młodzież na to, że Duch Święty uczy życia w prawdzie, 2. Daje siłę do wypełniania zaleceń Chrystusa, 3. Przede wszystkim Duch Święty uczy miłości: „[...] ponieważ miłość Boża wypełniła nasze serca przez Ducha Świętego, który jest nam dany” (Rz 5,5).

\section{BIBLIOGRAFIA}

Publikacje ks. F. Blachnickiego

Blachnicki F., Prawda - Krzyż - Wyzwolenie. Ku polskiej teologii wyzwolenia, Carlsberg 1985.

Blachnicki F., Charyzmat „Światło-Życie”. Teksty podstawowe, Lublin 1987.

Blachnicki F., Wychowanie do modlitwy, Lublin 1995.

Blachnicki F., Panie naucz nas modlić się, cz. 1, Krościenko 1999.

Blachnicki F., Formacja dojrzałych chrześcijan jako diakonia Ruchu, cz. 1 „Oaza” nr 6.

Blachnicki F., Homilie, w: Oaza Nowego Życia, dzień 4.

Gabriel Mar [Fr. Blachnicki], Problem formalnej zasady teologii pastoralnej i duszpasterstwa, AK 1966, t. 69.

Materiały Ruchu Światło-Życie

Biblioteka Animatora. Formacja podstawowa Służby Liturgicznej i Ruchu Światło-Życie, Kraków 1989.

Dziesięć kroków ku dojrzałości chrześcijańskiej. Pomoce formacyjne do spotkań i celebracji, Krościenko 2000.

Notatnik uczestnika formacji krok 3, s. 6-8.

Oazy modlitwy. Podręcznik Nowenny Jubileuszowej 2003/2004, Krościenko 2003.

Pomoce formacyjne do kroku 3.

Pomoce formacyjne do kroku 5.

\section{Literatura przedmiotu}

Dąbrowski K., Trud istnienia, Warszawa 1986.

Grzywak-Kaczyńska M., Trud rozwoju, Warszawa 1988.

35 Por. Notatnik uczestnika formacji krok 3, s. 6-8.

36 Por. Oaza modlitwy, s. 51-69; Pomoce formacyjne do kroku 3, s. 6-8. 
Jan Paweł II, Przemówienia, homilie w Polsce 31 maja - 10 czerwca 1997, Kraków 1997. Kozielecki J., Z Bogiem albo bez Boga, Warszawa 1991.

Kusz E., „Światło-Życie” jako integralna wizja wychowania, „Ethos” 6 (1993) 23, s. 162-168. Maslow A., Motywacja i osobowość, Warszawa 1990.

Posłuszny H., Potrzeby w służbie rozwoju dojrzałej osobowości, „Studia Włocławskie” 3 (2000), s. 238-246. 